systematic review and meta-analysis of randomised controlled trials. Bmj. 2013;347f5934.

4. Fischer L., Hildebrandt C., Bruckner T., Kenngott H., Linke G. R., Gehrig T., Buchler M. W., MullerStich B. P. Excessive weight loss after sleeve

\section{SLEEVE GASTRECTOMY FOR MORBID OBESITY - REGIONAL EXPERIENCE \\ KHATSIEV B. B., KUZMINOV A. N.}

This paper summarizes experience of 116 sleeve gastrectomies performed in Stavropol for the last three years. Average operative time was $110 \pm 51$ minutes. Complication rate was $6.9 \%$ with no mortality. 5 (4.3\%) patients were reoperated due to complications. Staple line leakage rate was $1.7 \%$.

Average excessive weight loss in 12 months after the surgery egualled operation was $57.3 \%$ with a regain up to $48.3 \%$ two years after the primary procedure. Sleeve gastrectomy demonstrated high efficacy in treatment of $2^{\text {nd }}$ type diabetes mellitus resolving it in all followed up patients. 5 pregnancies in previously infertile patients were reported.

Therefore, this operation may be recommended as standalone primary bariatric procedure.

Key words: bariatric surgery, sleeve gastrectomy, obesity gastrectomy: a systematic review. Obes Surg 2012;22(5):721-731

5. Yashkov Y., Khatsiev B., Kuzminov A. Data of the Russian National Bariatric Registry in 2012. Obesity Surgery. 2013;23(8):1076.

\section{ПРОАОАЬНАЯ РЕЗЕКЦИЯ ЖЕАУАКА \\ ПРИ МОРБИАНОМ ОЖИРЕНИИ - РЕГИОНААЬНЫЙ ОПЫТ}

Б. Б. ХАЦИЕВ, А. Н. КУЗЬМИНОВ

В статье суммируется опыт 116 продольных резекций желудка, выполненных в Ставрополе за последние 3 года. Среднее время операции составило $110 \pm 51$ минут. Частота осложнений составила 6,9 \% с нулевой летальностью. 5 (4,3 \%) пациентов были повторно оперированы в связи с осложнениями. Частота несостоятельности степлерной линии в анализируемой группе составила 1,7\%.

Среднее снижение избыточного веса через 12 месяцев после операции равнялось 57,3 \% с незначительным повторным набором - через два года после операции снижение избыточного веса было на уровне 48,3 \%. Продольная резекция желудка продемонстрировала высокую эффективность при сахарном диабете 2 типа у всех пациентов анализируемой группы. Кроме того, в послеоперационном периоде отмечена беременность у 5 пациенток, ранее лечившихся по поводу бесплодия.

Таким образом, наш опыт позволяет рекомендовать продольную резекцию желудка как первичную самостоятельную бариатрическую операцию.

Ключевые слова: бариатрическая хирургия, продольная резекция желудка, ожирение

\title{
APARASITISM AND ANTI-PARASITISM PRINCIPLE IN LIVER ECHINOCOCCOSIS SURGERY: RESULTS
}

\author{
Vafin A. Z., Aidemirov A. N., Abdokov A. D., Popov A. V., Mashurova E. V., Malanka M. I.
}

\section{Stavropol State Medical University, Russian Federation}

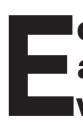
chinococcosis remains a severe disease affecting both animals and humans, which is associated with a longer course,

Vafin Albert, MD, PhD, Professor, Department of Hospital Surgery, Stavropol State Medical University;

tel.: (8652)717003; e-mail: azvafin@mail.ru

Aidemirov Artur, MD, PhD, Head of Department

of Hospital Surgery, Stavropol State Medical University;

tel.: 8(8652)479697; e-mail: aaidemirov@mail.ru

Abdokov Artur, MD, Assistant, Department of Hospital Surgery, Stavropol State Medical University;

tel. : 89283097050

Popov Alexander, MD; Deputy Chief, State Budgetary Healthcare Institution of Stavropol Region Stavropol regional clinical hospital tel.: 89054969703

Mashurova Ekaterina, MD; Assistant, Department of Hospital Surgery, Stavropol State Medical University; tel.: 89283395095 progressively aggravating condition and, if no treatment taken in due time, with a fatal outcome at an early age. Echinococcosis is spread in various countries of South Europe, Asia, and South America. In Russia, the endemic areas include the North Caucasus and the Stavropol Region namely as part of that. Echinococcosis may develop in any organs and tissues of the intermediate host while affecting the liver most often $[2,8,9]$.

In order to improve the surgical treatment of echinococcosis, our clinic (1980-1983) developed and introduced the general principles of aparasitism and anti-parasitism [4] to be further perfected, expanded, and implemented in clinical practices stage by stage $[5,6,7]$. 
Aparasitism is a set of measures taken prior to, and during the surgery, in order to prevent dissemination and implantation of echinococcosis germinal parts in the surgery area, and implying sticking strictly to such requirements as precise diagnostics of the pathology itself, its localization and the number of cysts; proper treatment strategy; rational surgical access; minimal traumatization of the cyst through revision and mobilization of the organ; thorough isolation of the surgical site, etc. The surgery of choice is a closed radical echinococcectomy allowing an operative intervention with prevention of dissemination and relapse. In case of an open echinococcectomy the mandatory part is evacuation of the cyst contents not allowing its contact with the surgical site and clothes, total removal of the cyst germinal parts, and of the cuticular membrane.

Anti-parasitism is a set of measures taken prior to, during, and after the surgery in order to neutralize germinal parts from the cyst, which have passed onto the affected organ or the ones nearby, onto the wound surface, the surgical clothes, all these also implying a number of specific requirements.

Unfortunately, the surgical practice cannot always imply complete aparasitism and anti-parasitism, yet the observance of these principles for any surgeries would help reduce significantly the risk of intra-operative dissemination; complications due to inflammatory infections, as well as echinococcosis relapse and post-operative complications.

The introduction of Ultrasound, CT, and MRT as tools for diagnosing echinococcosis revealed the importance of detecting precisely the location and the number of the cysts as well as offered a choice of the right operative approach. The plasma technologies when applied to echinococcosis surgical treatment brought the radical nature of the surgeries on a higher level. Generally speaking, all the major points for the aparasitism and anti-parasitism principles were introduced in clinical practice in 1992-1993 [7].

Purpose: clinical evaluation of the efficiency in relation to the aparasitism and anti-parasitism principle in liver echinococcosis surgeries.

Material and Methods. The outcomes after surgical treatment given to 558 patients with liver echinococcosis were analyzed: 100 patients who underwent surgeries in 1982-1990 after the basics of aparasitism and anti-parasitism principle were introduced (control group), and another 458 patients who underwent surgeries within the period 1991-2010, when the major rules for the named principle had already become a stable part of the clinical practice (main group).

Diagnostics. In 1982-1992 liver echinococcosis was diagnosed through a number of complementary methods including the Katsoni reaction, latex-agglutination test (LAT), indirect hemagglutination test (IHAT), gel double diffusion test (GDDT), and hydatid echinococcosis immune-enzyme assay (IEA), all of these allowing virtually $100 \%$ of the diagnosis reliability [1]. However, from 1993 on, due to some economic considerations, our clinic stopped employing all these diagnostic methods and performed the hydatid echinococcosis IEA alone, its diagnostic value reaching $92 \%$ [15].

The major methods used along with the IEA for local diagnostics of liver echinococcosis, are ultrasound scanning, X-Ray CT, and magnetic resonance tomography. For differential diagnostics of certain focal lesions in the liver fine needle aspiration biopsy and video laparoscopic surgery were employed [10, 12].

Surgical strategy. In case of cysts located in the VII-VIII liver segments the patients underwent rightside thoracophrenolaparotomy (59\%). In case of other cyst localization in liver other laparotomies were used - upper median laparotomy (25.7 \%); by Koher-Fedorov (14.8\%), and by Melnikov (0.5\%).

The statistical analysis was run on an IBM P-IV Computer using the statistic software BIOSTAT and the $\chi^{2}$ criteria to compare the sets of data.

Results and Discussion. The patients' age varied from 11 to 75 while most of those who underwent surgeries (66 \%) were $30-60$ years old; the male:female ratio was $1: 1.6$. Out of the 558 patients $83.2 \%$ were hospitalized with primary echinococcosis; $10.3 \%$ - with relapsed echinococcosis, while another $6.5 \%$ - with residual echinococcosis. $71.8 \%$ of patients in both groups were diagnosed with solitary liver cysts and $28.2 \%$ - with multiple cysts. Table 1 shows the pathology prevalence in different groups of patients with echinococcosis.

Table 1

\begin{tabular}{|l|c|c|}
\hline Liver echinococcosis & $\begin{array}{c}\text { Control } \\
\text { Group (\%) }\end{array}$ & $\begin{array}{c}\text { Main Group } \\
(\%)\end{array}$ \\
\hline 1. Primary, incl. & 85.0 & 83.8 \\
\hline - Solitary & 74.0 & 59.1 \\
\hline - Multiple & 11.0 & 24.7 \\
\hline 2. Relapse, incl. & 10.0 & 9.4 \\
\hline - Solitary & 6.0 & 6 \\
\hline - Multiple & 4.0 & 3.4 \\
\hline 3. Residual, incl. & 5.0 & 6.8 \\
\hline - Solitary & 4.0 & 4 \\
\hline - Multiple & 1.0 & 2.8 \\
\hline Total & 100.0 & 100.0 \\
\hline
\end{tabular}

Note: $\chi^{2}=14.08, p=0.003$, the differences between the two groups' variables are statistically significant

Complications. In the analyzed groups, the patients were diagnosed with non-complicated type of the disease in $82.7 \%$ of cases $-87.6 \%$ in the main group and $60 \%$ in the control group. Complications were identified in $17.3 \%$ of the patients $12.4 \%$ in the main group while in the control group this index was $40.0 \%$. Purulent cysts were found in $8.7 \%$ of the patients; $1.5 \%$ of the patients had cyst perforation into the bile ducts with cholangitis and jaundice developed in them; $1.5 \%$ had perforation 
into the abdominal cavity; $0.8 \%$ - into the pleural cavity and in another $0.5 \%$ - into the bronchi. $4.3 \%$ of the patients had calcified cysts (Table 2).

Table 2

Complications in liver echinococcosis

\begin{tabular}{|l|c|c|}
\hline \multicolumn{1}{|c|}{ Complicated disease } & $\begin{array}{c}\text { Control } \\
\text { Group } \\
(\%)\end{array}$ & $\begin{array}{c}\text { Main } \\
\text { Group } \\
(\%)\end{array}$ \\
\hline 1. Non-complicated & 60.0 & 87.6 \\
\hline 2. Complicated, incl. & 40.0 & 12.4 \\
\hline - cyst perforation into the bile ducts & 2.0 & 1.3 \\
\hline $\begin{array}{l}\text { - cyst perforation into the pleural } \\
\text { cavity }\end{array}$ & 3.0 & 0.4 \\
\hline - cyst perforation into the bronchi & 1.0 & 0.4 \\
\hline - cyst perforation into the abdominal \\
cavity & 3.0 & 1.1 \\
\hline - cyst purulence & 19.0 & 12.4 \\
\hline - calcified cyst & 12 & 2.7 \\
\hline Total & 100.0 & 100.0 \\
\hline
\end{tabular}

Note: $\chi^{2}=10.3, p=0.03$, the differences between the two groups' variables are statistically significant

Surgical treatment for liver echinococcosis. Closed echinococcectomy (by O. B. Milonov classification) was done to $8.4 \%$ of patients: $9 \%$ in the control group and $8.2 \%$ in the main one; open-type echinococcectomy - to $87.6 \%$ of the patients: $89 \%$ in the control group and $87.4 \%$ in the main group. $4 \%$ of the patients had combined echinococcectomy: $2 \%$ in the control group and $4.4 \%$ in the main group.

When eliminating the residual cavity capitonnage was done to $80.1 \%$ of the patients. The invagination method was used in $9.2 \%$ of the cases; omentoplasty was done to $6.7 \%$ of the patients; aplatization - in $2.1 \%$ of the cases; and marsupialization - in $1 \%$ of the control group patients. External cyst drainage alone was given to $1.4 \%$ of the patients in the main group.

In the main group all the surgeries were performed by a specialized team of thoracoabdominal surgeons strictly observing the aparasitism and anti-parasitism principle of echinococcosis surgeries. The following points were analyzed - diagnostic methods; surgical treatment; frequency and nature of complications in the post-operative period; duration of hospitalization including the post-operative stay; rate of lethal outcomes, and relapse rate.

After the liver echinococcectomy done through the traditional methods post-operative complications ( 111 episodes total) were observed in $16.4 \%$ of the patients (some of them had a combination of several types of complications).

In $7 \%$ of the control group patients the complications had lethal outcome $-3 \%$ of the cases developed liver-kidney failure; $1 \%$ - cardiovascular collapse, $2 \%$ developed diffuse purulent peritonitis, while another $1 \%$ had sepsis.

In the main group, post-operative complications were detected in $12.3 \%$ of the patients, whereas in $0.4 \%$ of the cases those proved lethal: 2 patients passed away due to cardiovascular collapse.

The data above suggest that in 1992-2010, due to rational use of advanced tools and diagnostic methods, optimal treatment strategy, and strict observance of the aparasitism and anti-parasitism principle, which was developed and implemented then, it was possible to reduce the echinococcosis post-operative complications from $36.0 \%$ in the control group to $12.3 \%$ in the main group, as well as the rate of post-operative lethal outcomes from $7 \%$ to $0.4 \%$; relapse rate - from $10 \%$ to $1.19 \%$, and the total number of days spent in the hospital from 28.6 to 15 (Table 3).

\begin{tabular}{|l|c|c|}
\multicolumn{2}{|c}{ Treatment outcomes } & \multicolumn{2}{c|}{ Table 3 } \\
\hline \multicolumn{1}{|c|}{ Treatment outcomes } & $\begin{array}{c}\text { Control } \\
\text { Group } \\
(\%)\end{array}$ & $\begin{array}{c}\text { Main } \\
\text { Group } \\
(\%)\end{array}$ \\
\hline 1. Post-operative complications & 36.0 & 12.3 \\
\hline 2. Lethal outcomes & 7.0 & 0.4 \\
\hline 3. Relapses & 10.0 & 1.19 \\
\hline $\begin{array}{l}\text { 4. Hospitalization duration } \\
\text { (days, total) }\end{array}$ & 28.6 & 15.0 \\
\hline $\begin{array}{l}\text { 5. Hospitalization duration } \\
\text { (days, after surgery) }\end{array}$ & 21.4 & 11.2 \\
\hline
\end{tabular}

In the recent years literature has offered data indicating a high rate of post-operative complications following liver echinococcectomy («closed», i.e. implying elimination of the residual cavity) - from $17.6 \%$ [16], $27.9 \%$ [13], to $30 \%$ [3]; purulence if residual cavities - $12.9 \%$ [11]. In remote post-operative periods, residual cavities yet remain in $15-21 \%$ of patients with $60-65 \%$ of them developing purulence [12]. Relapses were reported in $11.2 \%$ [20], $19 \%$ [19] and $25 \%$ of the patients [21].

V. N. Chernyshov et al. report some good outcomes of surgical treatment for echinococcosis in Russia [17] with residual cavities in the liver detected in $9.6 \%$ of the patients, the lethal outcome rate being no higher than $1.46 \%$, and the relapse rate at $6.8 \%$. "Open» echinococcectomy produced much poorer results [17].

All this means that the results represented above suggest improved outcomes of echinococcosis surgical treatment (irrespective of complications, type of the surgery itself, and elimination of the residual cavities) in case the principle of aparasitism and anti-parasitism is strictly observed as well as the advanced scientific technologies are employed.

\section{Conclusion}

1. The principle of aparasitism and antiparasitism when applied to echinococcosis surgery makes it possible to reduce significantly the risk of echinococcosis cyst germinal elements dissemination during the surgery; the rate of postoperative complications; the lethal outcome rate, as well as the relapse rate. 
2. Plasma surgery technologies employed for treating echinococcosis as a component in the aparasitism and anti-parasitism principle prove highly efficient.

\section{References}

1. Andreev A. V., Sahno V. D., Manuilov A. M., Shamahyan K. A. Methods of intervention radiology in patients with liver echinococcosis. Ann. Surg. Hepatol. 2005;2(1):9899.

2. Ahmedov I. G. Morphogenesis of liver hydatid cyst. Newsletter of Surg. 2003;1:70-76.

3. Ashurov T. A. Comparative evaluation of echinococcectomy methods for children. Dissertation summary ... Cand. of Med. Sc. Dushanbe; 2000. 20 p.

4. Vafin A. Z. Aparasitism and anti-parasitism principle for echinococcosis surgery. Relev. Issues of Medic. Stavropol; 1982. P. 194-200.

5. Vafin A. Z., Aidemirov A. N., Popov A. V. General principles of aparasitism and anti-parasitism for echinococcosis surgery. Volume of Congress of Surg. Society, Stavropol Region. Stavropol; 1997. P. 23-25.

6. Vafin A. Z., Aidemirov A. N., Popov A. V. To clinical evaluation of plasma scalpel. Plasma in Medicine and Biology, new technologies in Surgery: Abstr. From Reports at All-Rus. Scientific Conference. Smolensk; 1997. P. 1415.

7. Vafin A. Z. Aparasitism and anti-parasitism for surgical interventions in echinococcosis. Surgery. 1993;4:7074.

8. Gavrilin A. V., Kuntsevich G. I., Vishnevsky V. A. Liver echinococcosis. Surgery. 2000;8:39-46.

9. Dadvany S. A., Shkrob O. S., Lotov A. N., Musaev G. $\mathrm{H}$. Treatment of hydatid echinococcosis. Surgery. 2000;8:27-32.

10. Zeinalov N. A., Zeinalov S. M. Laparosopic echinococcectomy. Endoscopic surgery. 2004;5:58-66

11. Kubyshkin V. A., Vishnevsky V. L., Kaharov M. A. Evolu-

\section{APARASITISM AND ANTI-PARASITISM PRINCIPLE IN LIVER ECHINOCOCCOSIS SURGERY: RESULTS \\ VAFIN A. Z., AIDEMIROV A. N., ABDOKOV A. D., \\ POPOV A. V., MASHUROVA E. V., MALANKA M. I.}

To evaluate the results of surgical treatment for liver echinococcosis based on the aparasitism and anti-parasitism principle, an analysis of treatment outcomes was conducted involving 100 patients who underwent surgeries in 1982-1990, through conventional methods (control group) and another 458 patients who received treatment in 1991-2010 after the aparasitism and anti-parasitism principle had been introduced in clinical practice to the fullest extent (main group). The aparasitism and anti-parasitism principle and plasma technologies implemented for echinococcectomy allowed to significantly improve the outcomes of liver echinococcosis surgical treatment: the rate of postoperative complications was brought down from $36.0 \%$ (control group) to $12.3 \%$ (main group); the post-operative lethal rate reduced from $7 \%$ to $0.4 \%$ respectively; the relapse rate - from $10 \%$ to $1.19 \%$, while the total number of days spent in the hospital went down from 28.6 to 15.

Key words: liver echinococcosis; diagnostics; surgical treatment; aparasitism and anti-parasitism; plasma jet
3. Strict observance of the aparasitism and anti-parasitism principle as well as the advanced scientific technologies serve an efficient basis for further improvement of echinococcosis surgical treatment and the respective outcomes.

tion of surgical treatments for liver echinococcosis. Ann. Surg. Hepatol. 2002;7:18-22.

12. Musaev G. H. Hydatid echinococcosis: diagnostics and comprehensive treatment. Dissertation summary ... D-r of Med. Sc. M.; 2000. 41 p.

13. Muhiddinov N. D. Optimization of surgical practice for liver echinococcosis depending on cyst localization. Dissertation summary ... Cand. of Med. Sc. Dushanbe; 2000. 20 p.

14. Nazyrov F. G., Akalov H. A., Ikramov A. I. Minimum invasive interventions in treating purulent complications of liver echinococcosis. Ann. Surg. Hepatol. 2002;2(7):18-21.

15. Nazyrov F. G., Abdurahmanov B. A., Ilhamov F. A. Puncture and drainage of purulent residual cavities under CT control. Ann. Surg. Hepatol. 1998;3(3):324.

16. Nechitailo M. E., Bulanov K. I., Cherny V. V., Saenko V. F. Surgical treatment of liver echinococcosis. Ann. Surg. Hepatol. 2001;1(6):41-50.

17. Chernyshov V. N., Ivanov S. A. Liver echinococcosis surgery. Samara; 2005. $196 \mathrm{p}$.

18. Chernyshov V. N., Panfilov K. A., Bogdanov V. E. Treatment of liver hydatid echinococcosis. Surgery. 2005;9:39-44.

19. Bektas H., Lehener F., Werner U., Bartels M., Piso G., Schrem H., Klempnauer J. Surgical therapy of cystic echinococcosis of the liver. Am. J. Surg. 2001;126(5):369-373.

20. Cirenci A., Bertoldi I. Evolution of surgery for hydatidosis from 1950 for today: analysis of a personal experience. World. J. Surg. 2001;25(1):87-92.

21. Jorganci K., Sayek I. Surgical treatment of hydatid cysts of the liver in the era percutaneus treatment. Am. J. Surg. 2002;184(1):63-69.

\section{РЕЗУАЬТАТЫ ПРИМЕНЕНИЯ ПРИНЦИПА АПАРАЗИТАРНОСТИ И АНТИПАРАЗИТАРНОСТИ В ХИРУРГИИ ЭХИНОКОККОЗА ПЕЧЕНИ \\ А. 3. ВАФИН, А. Н. АИАЕМИРОВ, \\ A. А. АБАОКОВ, А. В. ПОПОВ \\ Е. В. МАШУРОВА, М. И. МАААНКА}

Для оценки результатов хирургического лечения эхинококкоза печени на основе соблюдения принципа апаразитарности и антипаразитарности проведен анализ результатов лечения 100 больных, оперированных в 1982 - 1990 гг. традиционными методами (контрольная группа), и 458 больных, лечившихся в 1991 - 2010 гг., когда принцип апаразитарности и антипаразитарности был внедрен в клинике в полном объеме (основная группа).

Соблюдение принципа апаразитарности и антипаразитарности и применение плазменных технологий при эхинококкэктомии позволило существенно улучшить результаты хирургического лечения эхинококкоза печени: послеоперационные осложнения снижены с 36,0 \% в контрольной группе до 12,3 \% - в основной, послеоперационная летальность снижена соответственно с 7 до 0,4 \%, рецидивы заболевания - с 10 \% до 1,19\% и общий койко-день - с 28,6 до 15.

Ключевые слова: эхинококкоз печени, диагностика, хирургическое лечение, апаразитарность и антипаразитарность, плазменный поток 